\title{
THERMODYNAMIC SIMULATION AND VALIDATION EXPERIMENT OF NEODYMIUM OXIDE REDUCTION INTO METALLIC NEODYMIUM BY METALLOTHERMIC PROCESS
}

\author{
SIMULASI TERMODINAMIKA DAN EKSPERIMEN VALIDASI \\ REDUKSI NEODIMIUM OKSIDA MENJADI LOGAM NEODIMIUM \\ MENGGUNAKAN METODE METALOTERMIK
}

\author{
ISYATUN RODLIYAH ${ }^{1}$, ANDINA SEPTIARANI ${ }^{1}$, HASUDUNGAN E. MAMBY ${ }^{1}$, ZULFIADI \\ ZULHAN ${ }^{2}$, and D. CRISTINA A. SITOMPUL ${ }^{3}$ \\ ${ }^{1} \mathrm{R} \& \mathrm{D}$ Centre for Mineral and Coal Technology \\ Jalan Jenderal Sudirman 623 Bandung 40211, West Java-Indonesia \\ Ph. (+6222) 6030483, Fax. (+6222) 6003373 \\ e-mail: isya@tekmira.esdm.go.id \\ ${ }^{2}$ Metallurgical Engineering, Bandung Institute of Technology, Bandung \\ Jalan Ganesha No. 10 Bandung 40132, West Java-Indonesia \\ ${ }^{3}$ Metallurgical Engineering, Sultan Ageng Tirtayasa University, Banten \\ Jalan Raya Jakarta Km 4, Panancangan, Cipocok Jaya, \\ Banjaragung, Kota Serang, Banten 42124
}

\begin{abstract}
Neodymium $(\mathrm{Nd}$ ) is one of the rare-earth elements (REEs) found in significant amount within monazite and bastnasite minerals. $\mathrm{Nd}$ is a ferromagnetic metal that is often used as a material to produce magnet, commonly known as a permanent magnet. Neodymium is alloyed with other metals such as iron and boron to form one of the strongest types of permanent magnet. This research aim is to study the reduction process of $\mathrm{Nd}$-oxide into $\mathrm{Nd}$-metal through the metallothermic process. The $\mathrm{Nd}$ metal product is expected to fulfill the material specification for a permanent magnet. Thermodynamics simulation of Nd reduction into its metal was conducted using ITB's licensed Factsage software. A validation experiment was conducted only to the Nd metal resulting simulation. The simulations involved some parameters, i.e. temperatures $\left(600,700,800,900,1000,1100\right.$ and $\left.1200{ }^{\circ} \mathrm{C}\right)$, types of fluxes $\left(\mathrm{CaCl}_{2}\right.$ and $\left.\mathrm{Ca}(\mathrm{OH})_{2}\right)$, composition of the reducing agent $(1 \mathrm{x}, 2 \mathrm{x}$ dan $3 \mathrm{x}$ of the stoichiometric calculations), types of the reducing agents ( $\mathrm{Ca}$ and $\mathrm{Mg}$ ), and types of feeds used ( $\mathrm{Nd}$-oxide and $\mathrm{Nd}$ chloride). The thermodynamic simulation shows that Nd metal was produced in a condition where the temperature should be $1100-1200{ }^{\circ} \mathrm{C}$ using $\mathrm{Ca}$ as the reducing agent and $\mathrm{CaCl}_{2}$ as the flux, while the amount of reducing agent has no effect on the resulted product. Validation result of the simulations shows that the Nd metal is formed up to $49 \%$ metal in a non-oxidative condition.
\end{abstract}

Keywords: neodymium, rare earth oxides, metallothermic, reduction, thermodynamic simulation

\section{ABSTRAK}

Neodimium (Nd) adalah salah satu unsur logam tanah jarang yang keberadaannya sangat signifikan didalam mineral monasit dan basnasit. Logam Nd memiliki sifat feromagnetik sebagai bahan magnet, yang lebih dikenal dengan magnet permanen. Nd jika dipadukan dengan logam lain seperti besi dan boron dapat membentuk magnet permanen yang memiliki sifat magnet sangat kuat. Penelitian ini difokuskan untuk mempelajari proses reduksi Nd-oksida menjadi logam Nd dengan metode metalotermik. Logam Nd yang dihasilkan diharapkan dapat memenuhi spesifikasi untuk bahan baku magnet permanen. Simulasi termodinamika proses reduksi untuk memprediksi proses reduksi dari oksida logam tanah jarang menjadi logamnya menggunakan FACTSAGE Software lisensi Institut Teknologi Bandung 
(ITB). Validasi simulasi dilakukan melalui percobaan terhadap proses simulasi yang menghasilkan logam Nd. Parameter yang dilakukan pada proses simulasi adalah; suhu reduksi (600, 700, 800, 900, 1000, 1100 dan $1200^{\circ} \mathrm{C}$ ), jenis fluks $\left(\mathrm{CaCl}_{2}\right.$ dan $\left.\mathrm{Ca}(\mathrm{OH})_{2}\right)$, komposisi reduktor (1x, 2x dan $3 x$ stoikiometri), jenis reduktor ( $\mathrm{Ca}$ dan $\mathrm{Mg}$ ) dan jenis umpan ( $\mathrm{Nd}$-oksida dan $\mathrm{Nd-klorida).} \mathrm{Hasil} \mathrm{simulasi} \mathrm{termodinamika}$ menunjukkan bahwa logam Nd dapat terbentuk pada kondisi proses: suhu 1100-1200 ${ }^{\circ} \mathrm{C}$ dengan reduktor $\mathrm{Ca}$ dan penambahan fluks $\mathrm{CaCl}_{2}$, jumlah reduktor tidak mempengaruhi produk yang dihasilkan. Hasil validasi dari simulasi menunjukkan bahwa logam Nd terbentuk dengan kadar $49 \%$ dalam suasana non-oksidasi.

Kata kunci: neodimium, oksida logam tanah jarang, metalotermik, reduksi, simulasi termodinamika

\section{INTRODUCTION}

Rare earth elements (REEs) are a group of 17 chemical elements on the periodic table that consists of lanthanides group (from lanthanum to lutetium), yttrium, and scandium. Neodymium is one of the REEs symbolized with $\mathrm{Nd}$ and an atomic number of 60 . It is present in a significant quantities in monazite and bastnäsiteminerals (Gupta and Krishnamurthy, 2005). The monazite deposits in Indonesia can be found in Bangka Belitung, Karimata/Ketapang, Rirang-Tanah Merah (Atmawinata, 2011).

REEs share some common properties; such as softness, ductility, malleability, reactivity and magnetic properties. Those properties, especially the latter, and the fact that rare earth magnets are the strongest type of magnets, have made REE useful for many applications (Manaf, 2007). Nd is considered a critical technology metal mostly used for permanent magnets, electric vehicles, harddisc drives, mobile phones and more (Riaño and Binnemans, 2015).

There are two important process steps of REEs extraction, one of them is the rareearth oxide separation in large scale, and the other is the production of rare-earth metal or rare-earth magnetic alloy from the oxide. This article is mainly devoted to the latter: obtaining the $\mathrm{Nd}$ metal from its oxide.

Rare earth oxides (RE-oxides) can be reduced into its metal through metallothermic or electrolysis processes. In electrolysis, the process can be carried out continuously (Claux, Serp and Fouletier, 2011). However, it requires relatively expensive and quite consumptive electrodes operating under high temperature (> $1000^{\circ} \mathrm{C}$ ), with a relatively low recovery of rare earth metal (REM) of $<40 \%$ (Zhu, 2014). In the metallothermic process, a non- oxidative condition is required and high energy is consumed while producing $>90 \%$ recovery of REM (Weber and Reisman, 2012).

Standard free energy data $\left(\Delta G^{0}{ }_{1000}\right)$ shows that $\mathrm{Ca}, \mathrm{Y}$, and heavy rare earth elements (Tb, Dy, Ho, Er, Tm, Yb, and Lu) can reduce $\mathrm{Nd}_{2} \mathrm{O}_{3}$ (Gupta and Krishnamurthy, 2005). At the beginning of 2013, there was no commercial producer of the reduction of REoxide into its rare-earth metal in the United States, while in Europe the situation is different; the production of rare-earth metal using molten salts announced in mid-2013 (Koltun and Tharumarajah, 2014). Brazil was a producer of misch metal in the early 1990s at a company named CIF. However, since 1996, CIF has been focusing on tantalum production using fluoride molten salts (De Campos, Rodrigues and De Castro, 2014) and no longer produce the rare-earth metal. Present day technology usually uses fluoride salts for the reduction of $\mathrm{Nd}$ oxide.

Reduction of RE-oxide for the preparation of high purity rare earth metal (REM) is a descendant of the Ames Process for the preparation of uranium for the Manhattan Project - the metallothermic reduction of an RE-fluoride using calcium as the reducing agent. RE-fluoride is prepared from high purity RE-oxide reacted with a fluorine bearing compound (Ames Laboratory, 2017).

Research on the reduction of $\mathrm{Nd}$-oxide has been done by researchers worldwide. Lee et al. (2016), studied the electrochemical reduction of $\mathrm{Nd}_{2} \mathrm{O}_{3}$ through co-reduction with $\mathrm{NiO}$ to increase the reduction degree of rare earth oxides in molten $\mathrm{LiCl}$ containing $1 \% \mathrm{wt}$ of $\mathrm{Li}_{2} \mathrm{O} . \mathrm{Nd}_{2} \mathrm{O}_{3}$ was successfully converted into its metal in the presence of $\mathrm{NiO}$ through the reduction of $\mathrm{NiO}$ to $\mathrm{Ni}$, followed by that of 
$\mathrm{Nd}_{2} \mathrm{O}_{3}$ on the produced $\mathrm{Ni}$ to form an intermetallic $\mathrm{NdNi}_{5}$, continued with the reduction of $\mathrm{NdNi}_{5}$. Biswas et al. (1998), synthesized Nd-aluminide through aluminothermic reduction of neodymium oxide, even though the standard free energy change associated with the reduction of $\mathrm{Nd}_{2} \mathrm{O}_{3}$ by $\mathrm{Al}$ is positive (unspontaneous).

In Indonesia, the magnet products, particularly the permanent magnets (NdFeB) available on the market, are still entirely dependent on the imported product. The needs of permanent magnets in Indonesia are very high (Benecki, 2008). Therefore, mastering manufacture technology of permanent magnets from national resources, in this case, the rare earth metal as raw materials, is the utmost importance. Sharma (1986) in US Patent No. 4.578.242 carried out a reduction process of $\mathrm{Nd}$-oxide using $\mathrm{Na}$ metal as reducing agent and $\mathrm{CaCl}_{2}$ as flux and added by $\mathrm{Zn}$ metal which forms a low eutectic melting temperature with $\mathrm{Nd}$ (around $630^{\circ} \mathrm{C}$ ) and resulted in alloy metal of $\mathrm{Nd}-\mathrm{Zn}$. Refining was done by evaporating $\mathrm{Zn}$ at its boiling point $\left(907^{\circ} \mathrm{C}\right)$ and left $\mathrm{Nd}$ in a form of its metal. This was due to the high boiling point of $\mathrm{Nd}\left(3150^{\circ} \mathrm{C}\right)$. In this research, some innovations were done, i.e. reducing $\mathrm{Nd}$-oxide without going through the formation of $\mathrm{Nd}-\mathrm{Zn}$ alloy (direct reduction) and replace reducing agent with other metals that are less explosive than $\mathrm{Na}$ metal. Thus, it was expected that the $\mathrm{Nd}$ metal produced yields high purity (higher than $95 \%$ ) in a shorter processing time.

Similar research was done by Saleh (2015) with the purpose of reducing cerium oxide $\left(\mathrm{CeO}_{2}\right)$ into its cerium $(\mathrm{Ce})$ metal. The reduction was carried out through the metallothermic process using magnesium powder $(\mathrm{Mg})$ as the reducing agent and calcium chloride $\left(\mathrm{CaCl}_{2}\right)$ as flux. From the research, $50 \%$ of $\mathrm{Ce}$ metal was recovered with the purity of $91 \%$ at the temperature of $1200{ }^{\circ} \mathrm{C}$ for 3 hours using $1 \%$ of flux and $1: 1$ composition of $\mathrm{CeO}_{2}$ and $\mathrm{Mg}$.

Prior to the experimental research of $\mathrm{Nd}$ oxide reduction into its metal, the thermodynamic simulation was done using Factsage 6.4 (license owned by Bandung
Institute of Technology). Factsage was used to simulate/predict the reduction and refining process of the rare earth without doing any experimental research. Nevertheless, experimental research is important and needs to be done in order to validate the calculation/simulation result from Factsage. Thus, Factsageacts as a 'preliminary study' to obtain the illustration/prediction of the reduction process and its result.

The purpose of this research was to study the reduction process of $\mathrm{Nd}$-oxide into its metal through thermodynamics simulation using Factsage software (ITB's licensed) to predict the result of the reduction and the refining processes without doing any experimental research. It was expected that by doing the thermodynamic simulation, the preparation of $\mathrm{Nd}$-metal from its oxide through experimental research can be more efficient, time-effective with greater probability to be succeeded.

\section{METHODOLOGY}

Nd-oxide used as raw material in this study was obtained from commercial $\mathrm{Nd}$-oxides. Reduction of $\mathrm{Nd}$-oxide $\left(\mathrm{Nd}_{2} \mathrm{O}_{3}\right)$ was conducted using metal powder of $\mathrm{Ca}$ (calcium), $\mathrm{Al}$ (aluminium) and $\mathrm{Mg}$ (magnesium) as the reducing agents with the addition of $\mathrm{Ca}(\mathrm{OH})_{2}$ and $\mathrm{CaCl}_{2}$ as the fluxes. Flow diagram of $\mathrm{Nd}$-oxide reduction can be seen in Figure 1. RE-oxides can be reduced by a metallothermic method using alkali metals as reducing agents such as $\mathrm{Li}$, $\mathrm{Na}, \mathrm{K}, \mathrm{Mg}$, $\mathrm{Ca}$ and $\mathrm{Al}$ because they are more stable than RE-oxides (Krishnamurthy and Gupta, 2015).

Equipment used for the reduction of $\mathrm{Nd}$ oxide were as follows: press machine, tube furnace, combustion boat, crucible, muffle furnace and resistance furnace.

The parameters studied for simulation process were the types and amount of the reducing agents of $\mathrm{Ca}$ and $\mathrm{Mg}(1 \mathrm{x}, 2 \mathrm{x}$ and $3 x$ of stoichiometric calculation), the types of feed $\left(\mathrm{Nd}_{2} \mathrm{O}_{3}\right.$ and $\left.\mathrm{NdCl}_{3}\right)$, and the reduction of temperature $(600,700,800,900,1000$, $\left.1100,1200^{\circ} \mathrm{C}\right)$. 


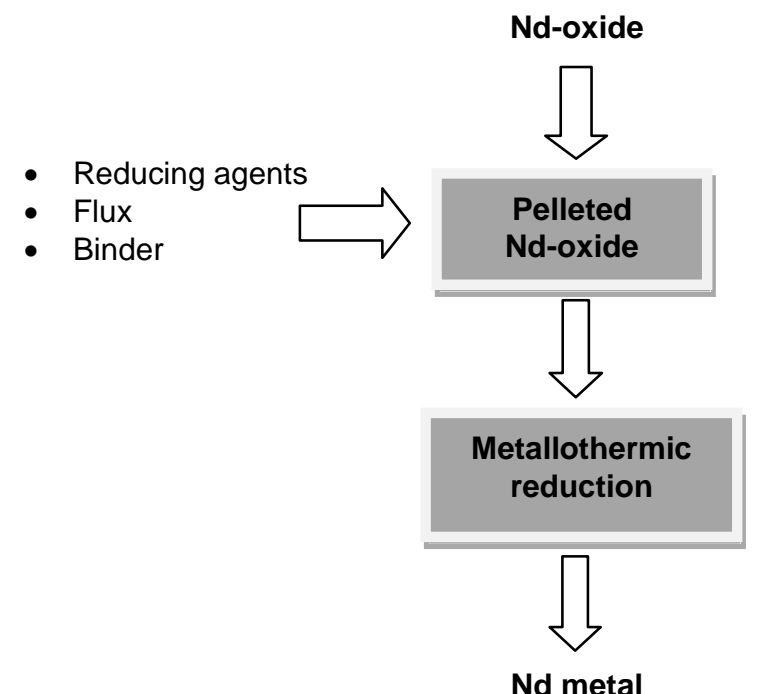

Figure1. Flowchart of the reduction of $\mathrm{Nd}$-oxide into $\mathrm{Nd}$ metal based on metallothermic process.

The reduction process for validation was carried out in a non-oxidative condition using inert gases (nitrogen and argon) to dissipate oxygen gas. After the reduction process, the metal phase and the slag produced were then separated using hand magnet (slag is non-magnetic material while metal is magnetic material) and analyzed using XRD and SEM analysis to further clarify the composition of the elements contained in the resulted product.

\section{RESULTS AND DISCUSSION}

This research was based on thermodynamics simulation to predict the condition of the reduction process using Factsage software. Factsage has been widely used in the calculation of thermodynamic equilibrium in combustion, slagging, corrosion, and reduction process taking place in a metallurgical plant. The calculation principle was based on the minimum total free energy in a system. When the total free energy in a system is minimum, the system reaches equilibrium, where all occurring reactions reaches the equilibrium. Thus, the thermodynamics calculation can be used to predict chemical and physical process rapidly.
The variable parameters applied in this simulation to determine the most suitable process were types of reducing agent and types of feed.

1. Types of reducing agent

This simulation was conducted to determine the best reducing agent to produce the Nd-metal. The reducing agents used in this simulation were $\mathrm{Ca}$ and $\mathrm{Mg}$. The result of simulation using $\mathrm{Ca}$ are shown in Figure 2 while that of $\mathrm{Mg}$ are in Figure 3.

Figure 2 shows that $\mathrm{Ca}$ metals started to reduce the $\mathrm{Nd}$-oxide $\left(\mathrm{Nd}_{2} \mathrm{O}_{3}\right)$ at the minimum temperature of $1100^{\circ} \mathrm{C}$. At the temperature of $600-1000^{\circ} \mathrm{C}$, there were no Nd metals formed. Reaction during the process is as follows:

$$
\mathrm{Nd}_{2} \mathrm{O}_{3(\mathrm{~s})}+3 \mathrm{Ca}(\mathrm{s}) \rightarrow 2 \mathrm{Nd}_{(\mathrm{s})}+3 \mathrm{CaO}(\mathrm{s})
$$

Figure 3 shows that the reduction of $\mathrm{Nd}$ oxide using Mg did not produce its metal, even if the temperature was raised up to $1200^{\circ} \mathrm{C}$.

Thus, it can be stated that the suitable reducing agent to reduce $\mathrm{Nd}$-oxide into its metal is $\mathrm{Ca}$ at the minimum temperature of $1000^{\circ} \mathrm{C}$. 


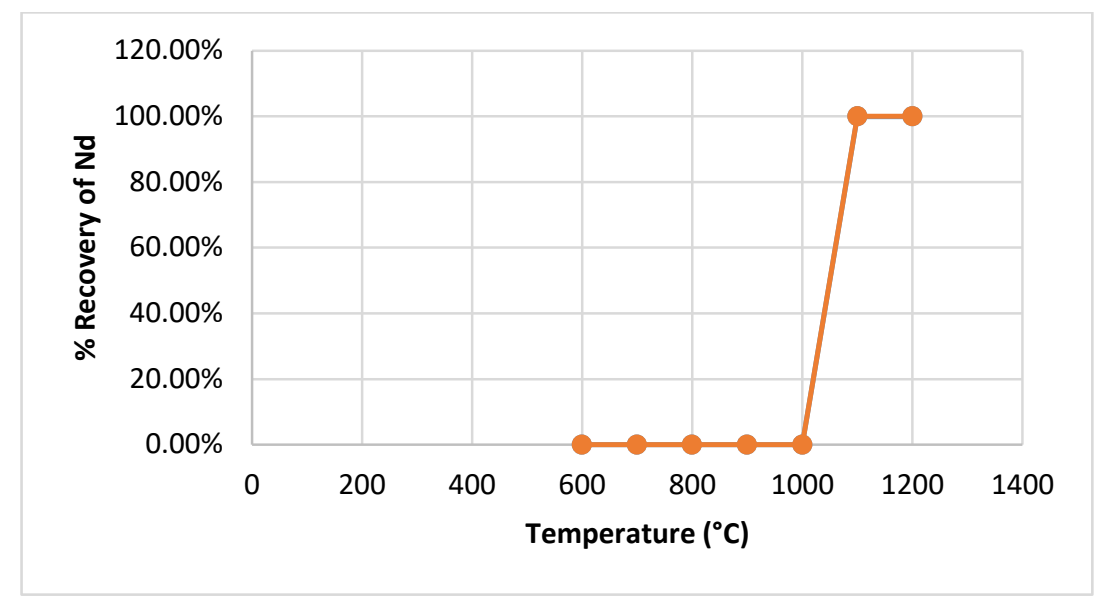

Figure 2. The relation between temperature and neodymium recovery using calcium as reducing agent

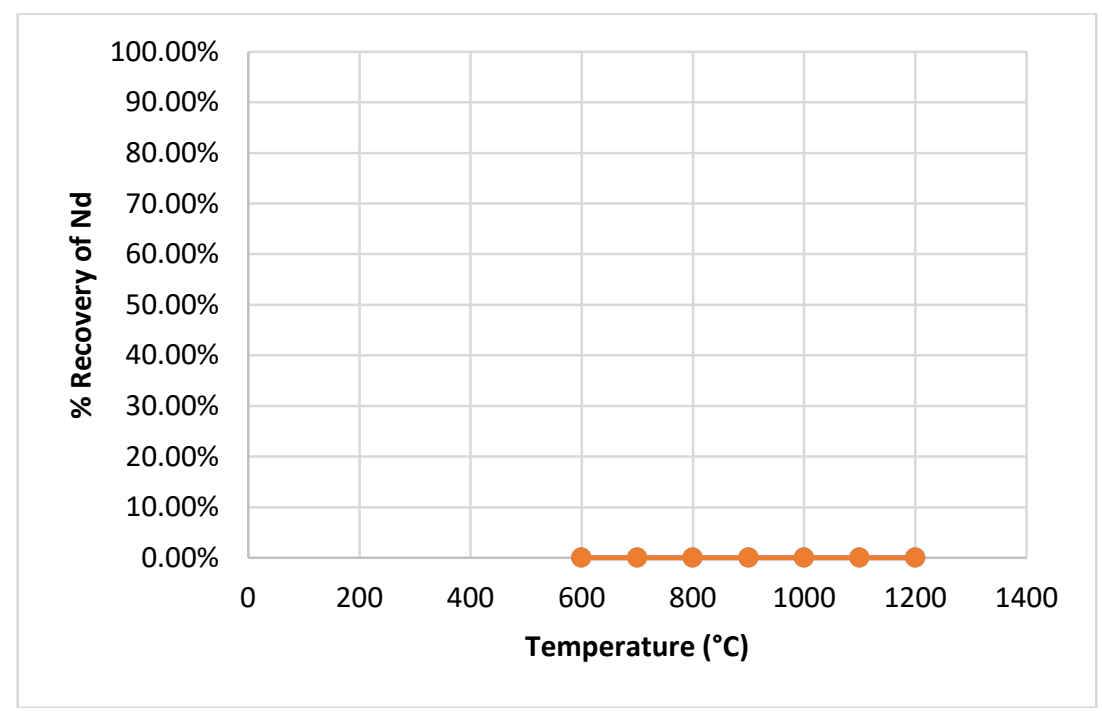

Figure 3. The relation between temperature and neodymium recovery using magnesium as reducing agent

The selection of the suitable reducing agent can be predicted from the standard free energy formation $\left(\Delta G^{0}\right)$. The reduction process occurs if the difference of $\Delta \mathrm{G}^{0}$ of $\mathrm{Nd}_{2} \mathrm{O}_{3}$ with $\Delta \mathrm{G}^{0}$ of $\mathrm{CaO}$ is negative. The Ellingham Diagram given in Figure 4 shows the relation of free energy and the temperature of the reaction.

Figure 4 shows that the elements that were able to reduce rare earth-oxides were very limited. In the standard condition, the order of the oxide stability is $\mathrm{CaO}>\mathrm{RE}_{2} \mathrm{O}_{3}>\mathrm{MgO}>\mathrm{Al}_{2} \mathrm{O}_{3}>>\mathrm{SiO}_{2}$. However, there are more elements that able to reduce the rare earth-chlorides, i.e. $\mathrm{KCl}>\mathrm{NaCl} \approx \mathrm{LiCl} \approx \mathrm{CaCl}_{2}>\mathrm{RECl}_{3}>\mathrm{MgCl}_{2}>$
$>\mathrm{AlCl}_{3}$. Calcium is the only metal element able to reduce both rare earth-oxides and chlorides into their metals. The statement is true based on both simulation results and the Ellingham Diagram.

2. Thermodynamic simulation using various types of feed

This simulation was done to determine which types of feed (types of $\mathrm{Nd}$ compound) able to produce highest recovery of $\mathrm{Nd}$ through metallothermic reduction. Based on Ames Process, it was suggested to use RE-chlorides as the feed instead of RE-oxides in order to obtain higher recovery (Riedemann, 2011). Figure 5 shows the simulation 
results using $\mathrm{Nd}$-chloride as the feed and $\mathrm{Ca}$ as the reducing agent, while Figure 6 shows simulation results using $\mathrm{Nd}$ chloride with $\mathrm{Mg}$ as the reducing agent.
Figures 5 and 6 show that $\mathrm{Ca}$ and $\mathrm{Mg}$ powder, acts as the reducing agent, was able to reduce $\mathrm{Nd}_{2} \mathrm{Cl}_{3}$ at a minimum temperature of $1100^{\circ} \mathrm{C}$.

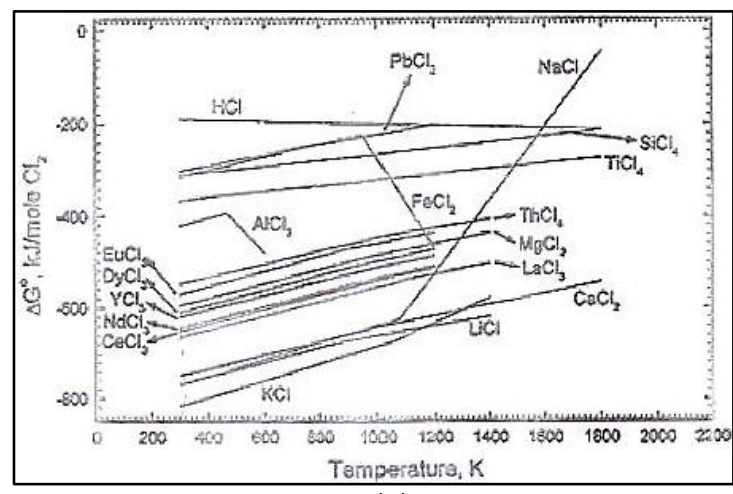

(a)

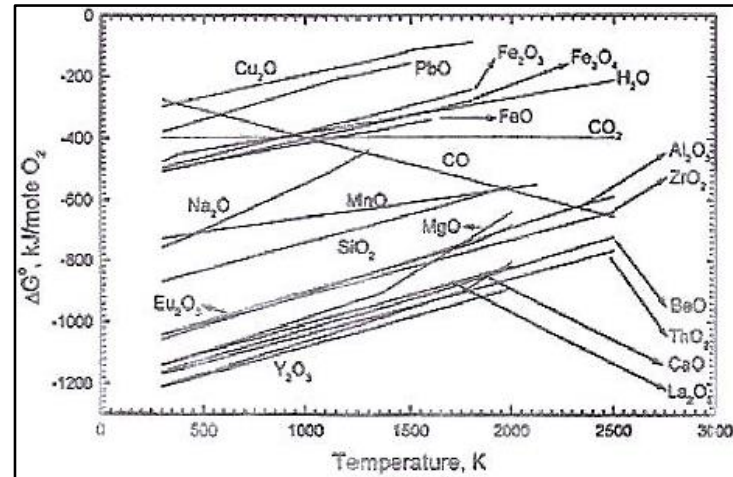

(c)

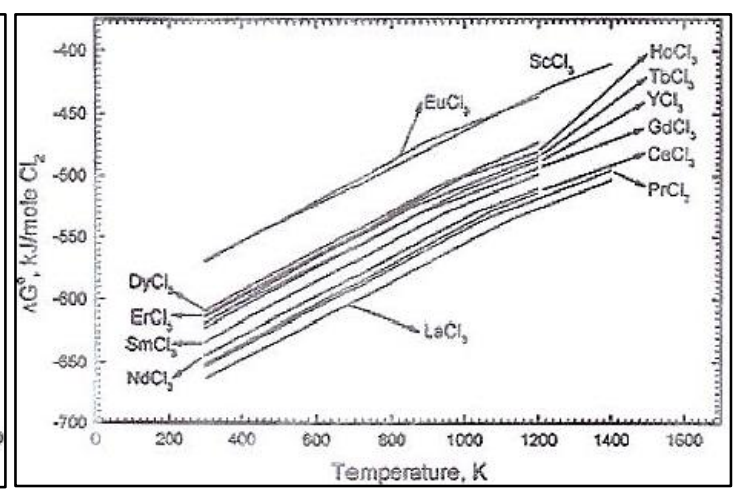

(b)

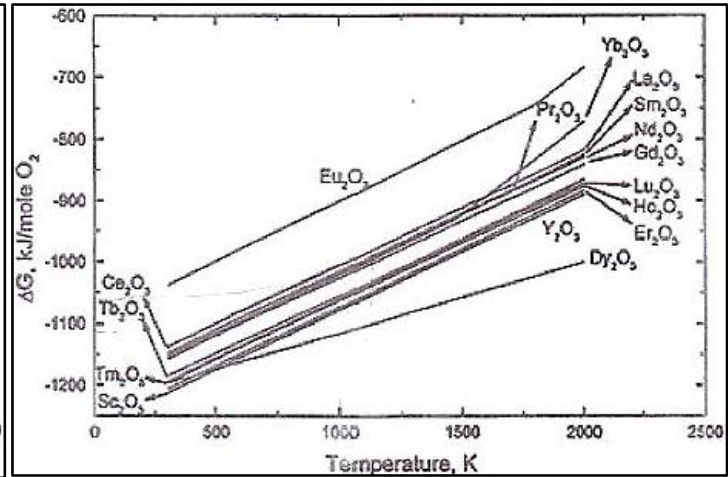

(d)

Figure 4. (a) and (b) Standard free energy formation of various rare earth elements and metal chlorides as the function of temperature, (c) and (d) Standard free energy formation of the various rare earth elements and metal oxides as the function of temperature

(Ellingham, 1944; Richardson and Jeffes, 1948)

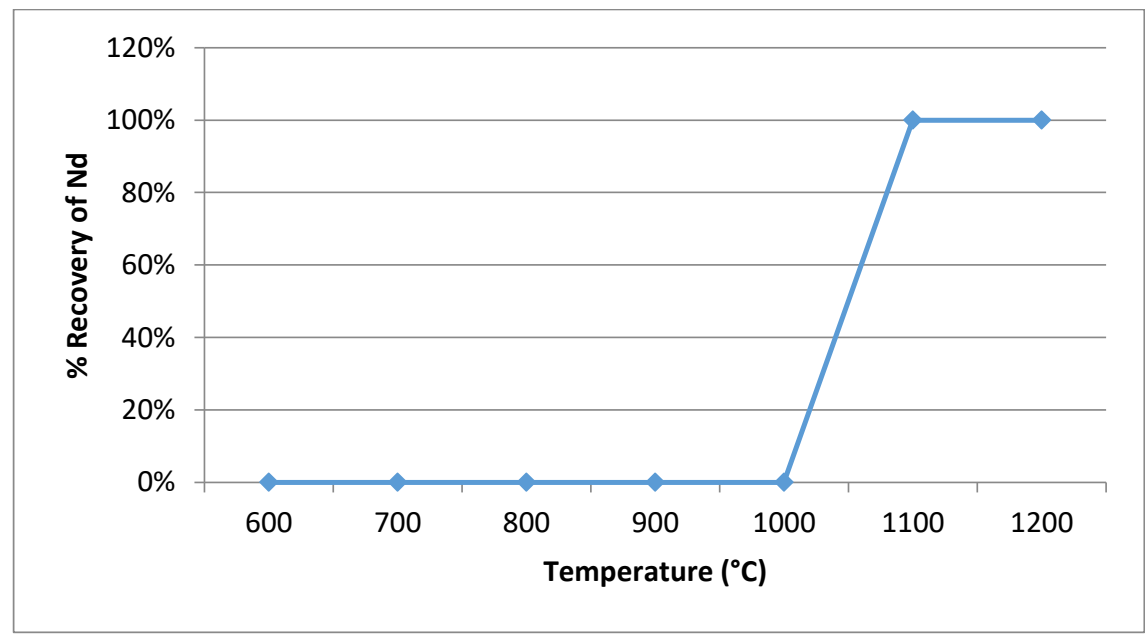

Figure 5. Recovery of metallic-Ndvs temperatures using $\mathrm{NdCl}_{3}$ as the feed and $\mathrm{Ca}$ as the reducing agent. 


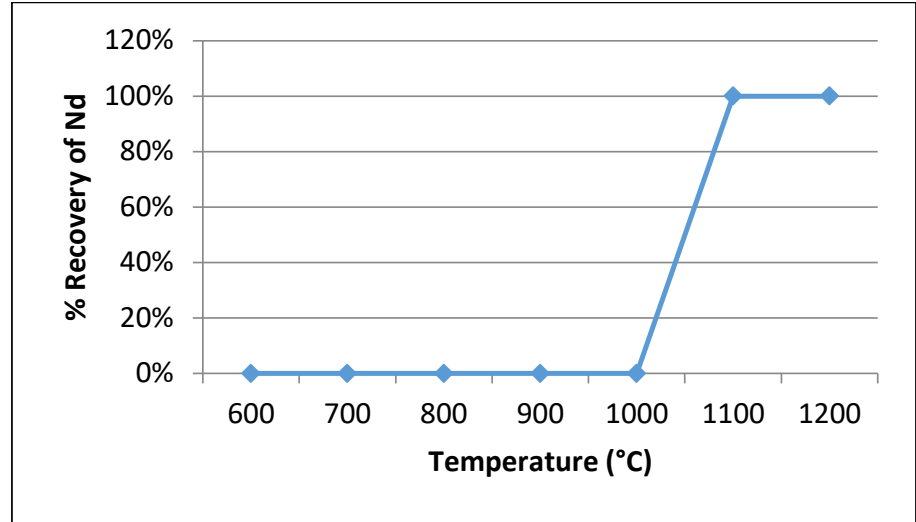

Figure 6. Recovery of metallic-Ndvs temperature using $\mathrm{NdCl}_{3}$ as the feed and $\mathrm{Mg}$ as the reducing agent.

Based on Figures 5 and 6, it can be stated that by combining $\mathrm{Nd}_{2} \mathrm{O}_{3}$ as the feed and $\mathrm{Mg}$ as the reducing agent did not produce $\mathrm{Nd}$ metal. However, by converting the $\mathrm{Nd}_{2} \mathrm{O}_{3}$ into its chloride salt first $\left(\mathrm{NdCl}_{3}\right)$, at the temperature of 1100 and $1200{ }^{\circ} \mathrm{C}$, the $\mathrm{Nd}$ metal was started to be formed.

After completing the thermodynamics simulation, the next step was validation experiment. The validation experiment was done only to the $\mathrm{Nd}$ metal resulting simulations, i.e. using both types of feed $\left(\mathrm{Nd}_{2} \mathrm{O}_{3}\right.$ and $\left.\mathrm{Nd}_{2} \mathrm{Cl}_{3}\right)$ with $\mathrm{Ca}$ as the reducing agent at the temperature of $1100-1200{ }^{\circ} \mathrm{C}$. The reduction of $\mathrm{Nd}$-oxide into its metal was conducted using commercial $\mathrm{Nd}$-oxide. The ICP analysis to determine the chemical composition of the commercial $\mathrm{Nd}$-oxide can be seen in Table 1.
Table 1. ICP analysis of commercial

\begin{tabular}{cc}
\hline Element / Compound & Composition(\%) \\
\hline $\mathrm{Nd}$ & 85.29 \\
$\mathrm{Sm}$ & 1.59 \\
$\mathrm{Gd}$ & 0.77 \\
$\mathrm{Dy}$ & 0.73 \\
$\mathrm{Ce}$ & 0.61 \\
$\mathrm{Pr}$ & 0.58 \\
$\mathrm{La}$ & 0.22 \\
$\mathrm{CaO}$ & 0.49 \\
$\mathrm{Fe}_{2} \mathrm{O}_{3}$ & 0.17 \\
\hline
\end{tabular}

The experiments were carried out using various compositions of fluxes and a reducing agent at the temperature of 1200 ${ }^{\circ} \mathrm{C}$ for 4 hours using $\mathrm{Ca}$ as the reducing agent with the addition of $\mathrm{CaCl}_{2}$ and $\mathrm{NaCl}$ as the fluxes. Prior to the experiments, the parameters were varied (Table 2) and simulated (Figure 7) to predict the amount of $\mathrm{Nd}$ metal formed.

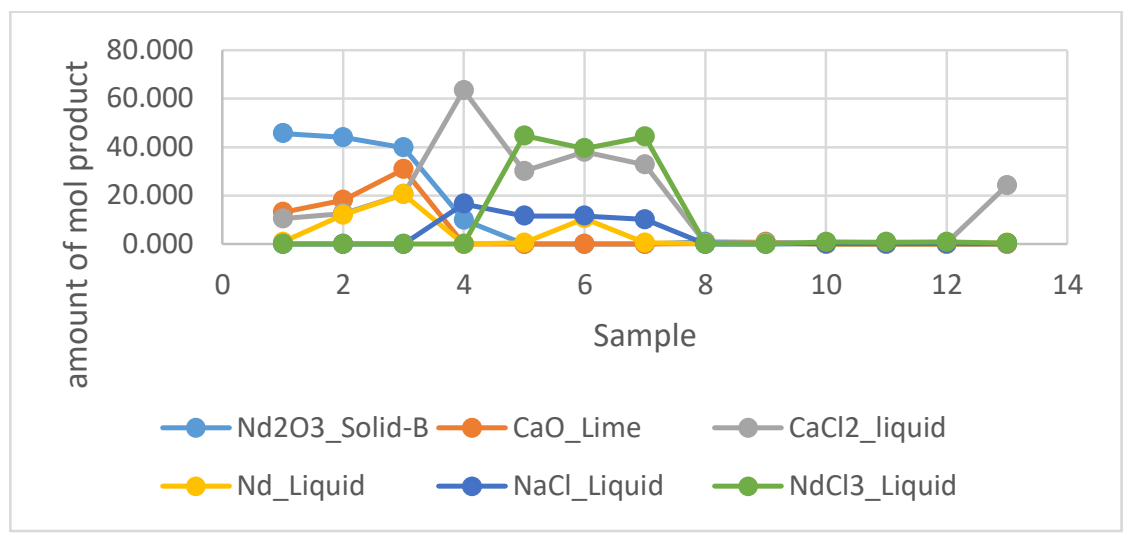

Figure 7. Recovery of $\mathrm{Nd}$ metal vs variation of the feeds at the temperature of $1200^{\circ} \mathrm{C}$. 
Table2. Variation of the experiment's parameters

\begin{tabular}{|c|c|}
\hline Sample 1 & $\mathrm{~d}_{2} \mathrm{O}_{3}$ as the feed with the exact amount of stoichiometric calculation \\
\hline Sample 2 & $\mathrm{~d}_{2} \mathrm{O}_{3}$ as the feed with $10 \%$ excess of $\mathrm{Ca}$; flux consisted of $70 \%$ of $\mathrm{CaCl}_{2}$ and $30 \%$ of $\mathrm{NaCl}$ \\
\hline & jichiometric calculation \\
\hline & $\begin{array}{l}\text { e feed with } 10 \% \text { excess of } \mathrm{Ca} \text {; flux consisted of } 70 \% \text { excess } \\
\mathrm{aCl}\end{array}$ \\
\hline e 5 & ed with the exact amount of stoichiometric calculation \\
\hline & $\mathrm{NdCl}_{3} \mathrm{a}$ \\
\hline San & onsisted of $70 \%$ excess of $\mathrm{C}$ \\
\hline Sample 8 & $\begin{array}{l}\mathrm{NdCl}_{3} \text { as the feed with } 10 \% \text { excess of Ca;flux consisted of } 70 \% \text { of } \mathrm{CaCl}_{2} 70 \% \text { and } 30 \% \text { of } \mathrm{NaCl} \\
\mathrm{Nd}_{2} \mathrm{O}_{3} \text { as the feed with the exact amount of stoichiometric calculation }\end{array}$ \\
\hline Sam & $0 \%$ excess of $\mathrm{CaCl}_{2}$ and $30 \%$ \\
\hline le 10 & excess of $\mathrm{NaCl}$ \\
\hline Sample 11 & $\begin{array}{l}\mathrm{NdCl}_{3} \text { as the feed with } 10 \% \text { excess of } \mathrm{Ca} \text {; flux consisted of } 70 \% \text { excess of } \mathrm{CaCl}_{2} \text { and } 30 \% \\
\text { excess of } \mathrm{NaCl}\end{array}$ \\
\hline ample 12 & $\mathrm{IdCl}_{3}$ as the feed with $10 \%$ excess of Ca;flux consisted of $70 \%$ of $\mathrm{CaCl}_{2} 70 \%$ and $30 \%$ of $\mathrm{NaCl}$ \\
\hline
\end{tabular}

Figure 7 shows that $\mathrm{Nd}$ metal was formed in samples no. 2, 3, and 6 . The formation of liquid $\mathrm{Nd}$ from Factsage simulation indicated the formation of $\mathrm{Nd}$ metal in a form of liquid. The highest $\mathrm{Nd}$ metal recovery was 20 moles (sample no 3) achieved using $\mathrm{Nd}_{2} \mathrm{O}_{3}$ as the feed with $10 \%$ excess of $\mathrm{Ca} ; 70 \%$ excess of $\mathrm{CaCl}_{2}$; and $30 \%$ excess of $\mathrm{NaCl}$, reduced at the temperature of $1200{ }^{\circ} \mathrm{C}$ for 4 hours in a non-oxidative condition. $\mathrm{Nd}$ - chloride $\left(\mathrm{NdCl}_{3}\right)$, an intermediate product, was formed using samples no 5,6 , and 7 , while the products of samples 3 and 4 were still in a form of Nd-oxide.

Figure 8 to Figure 14 show the SEM-EDS result analysis for the validation experiment for samples no. 2, 3, 4, 7, 8, 9, and 10 respectively (produced the intermediate product Nd-chloride or Nd metal).
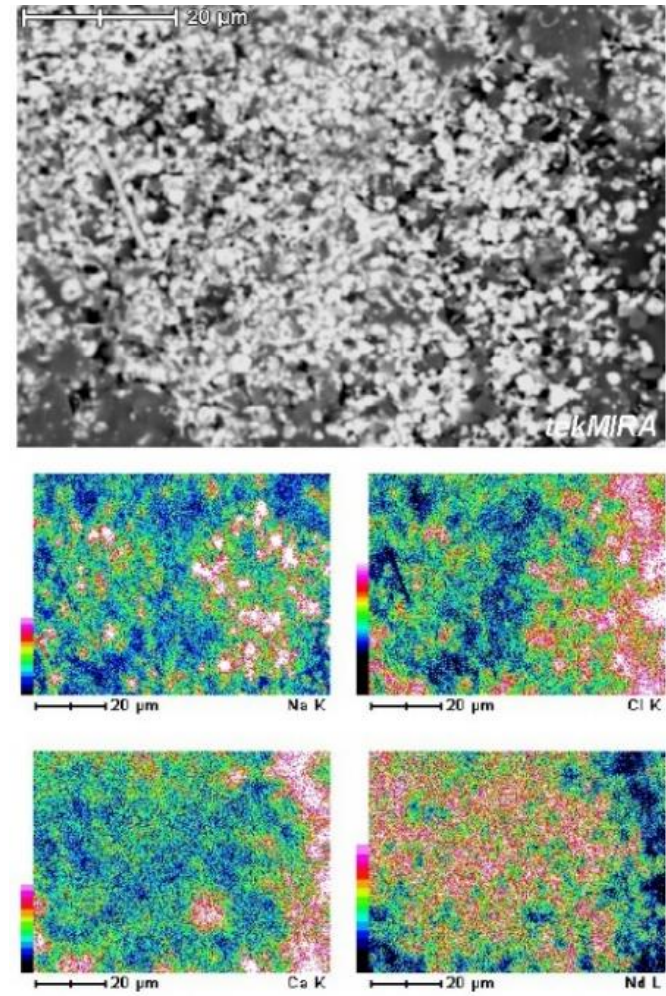

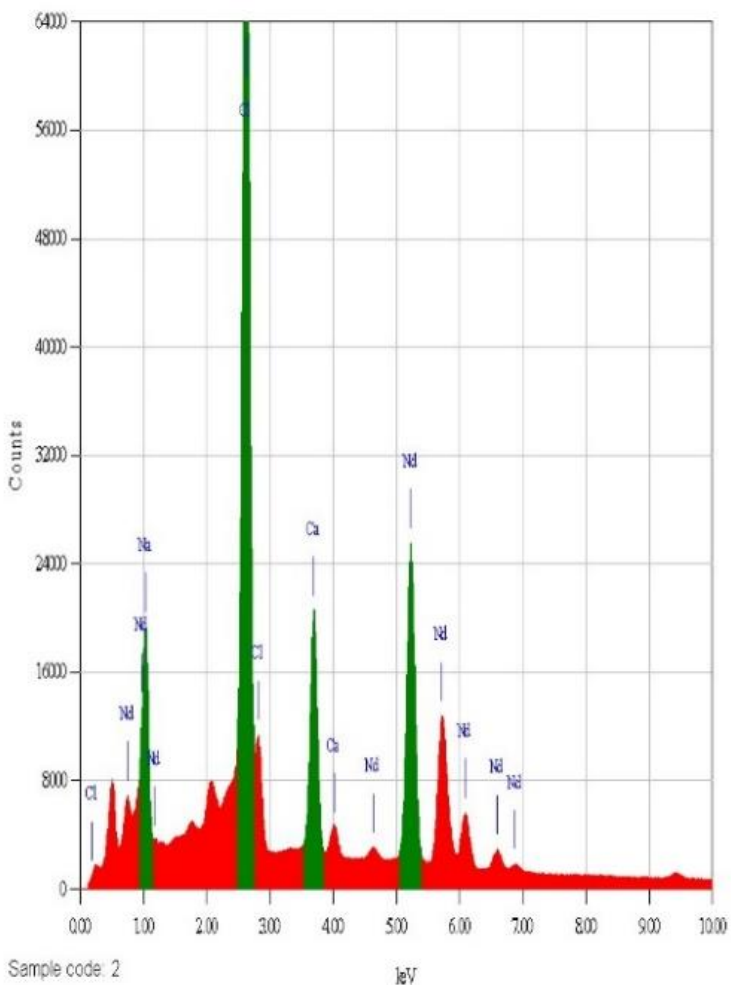

Figure 8. SEM-photomicrograph (left figure) and SEM-EDS (right figure) analysis results on sample 2. 
Thermodynamic Simulation of Neodymium Oxide Reduction into... Isyatun Rodliyah et al.
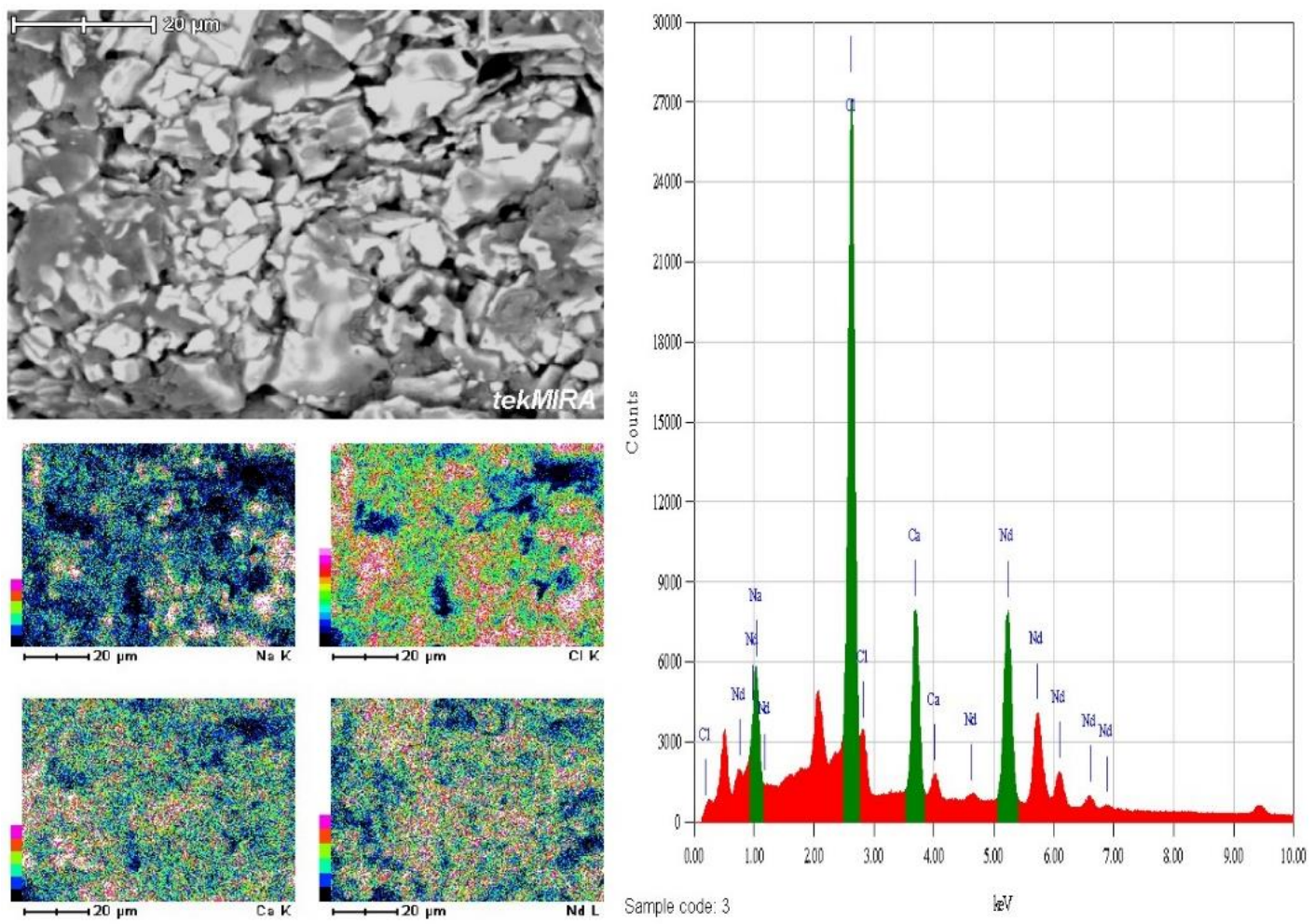

Figure 9. SEM-photomicrograph (left figure) and SEM-EDS (right figure) analysis results on sample 3.
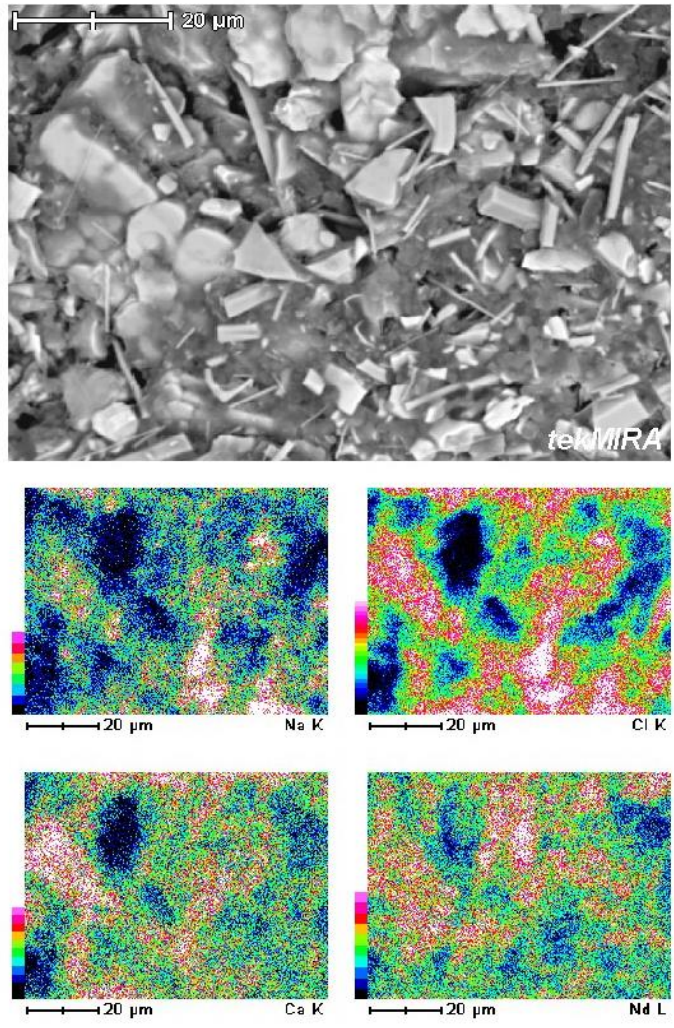

Figure 10. SEM-photomicrograph (left figure) and SEM-EDS (right figure) analysis results on sample 4. 

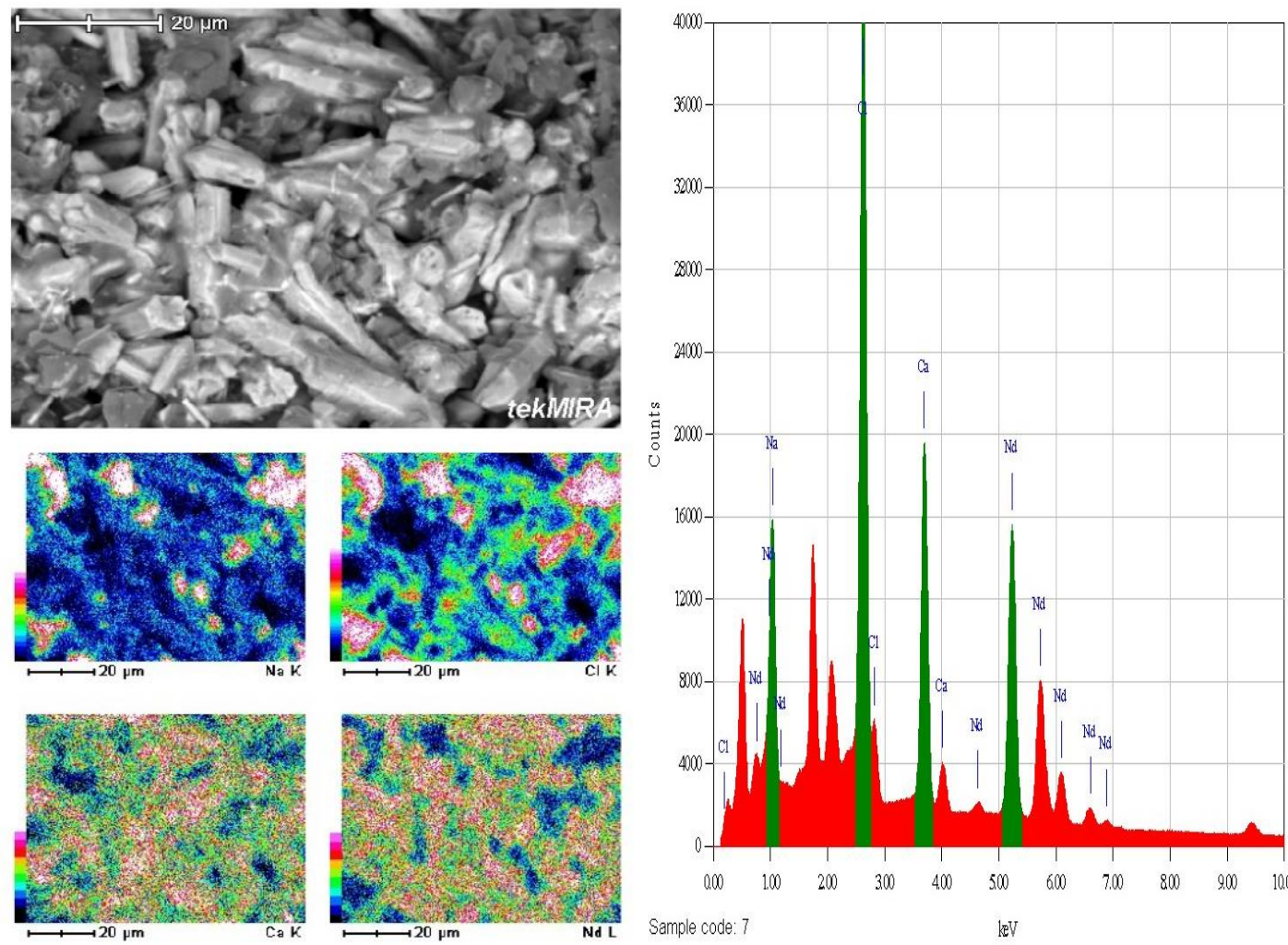

Figure 11. SEM-photomicrograph (left figure) and SEM-EDS (right figure) analysis results on sample 7.
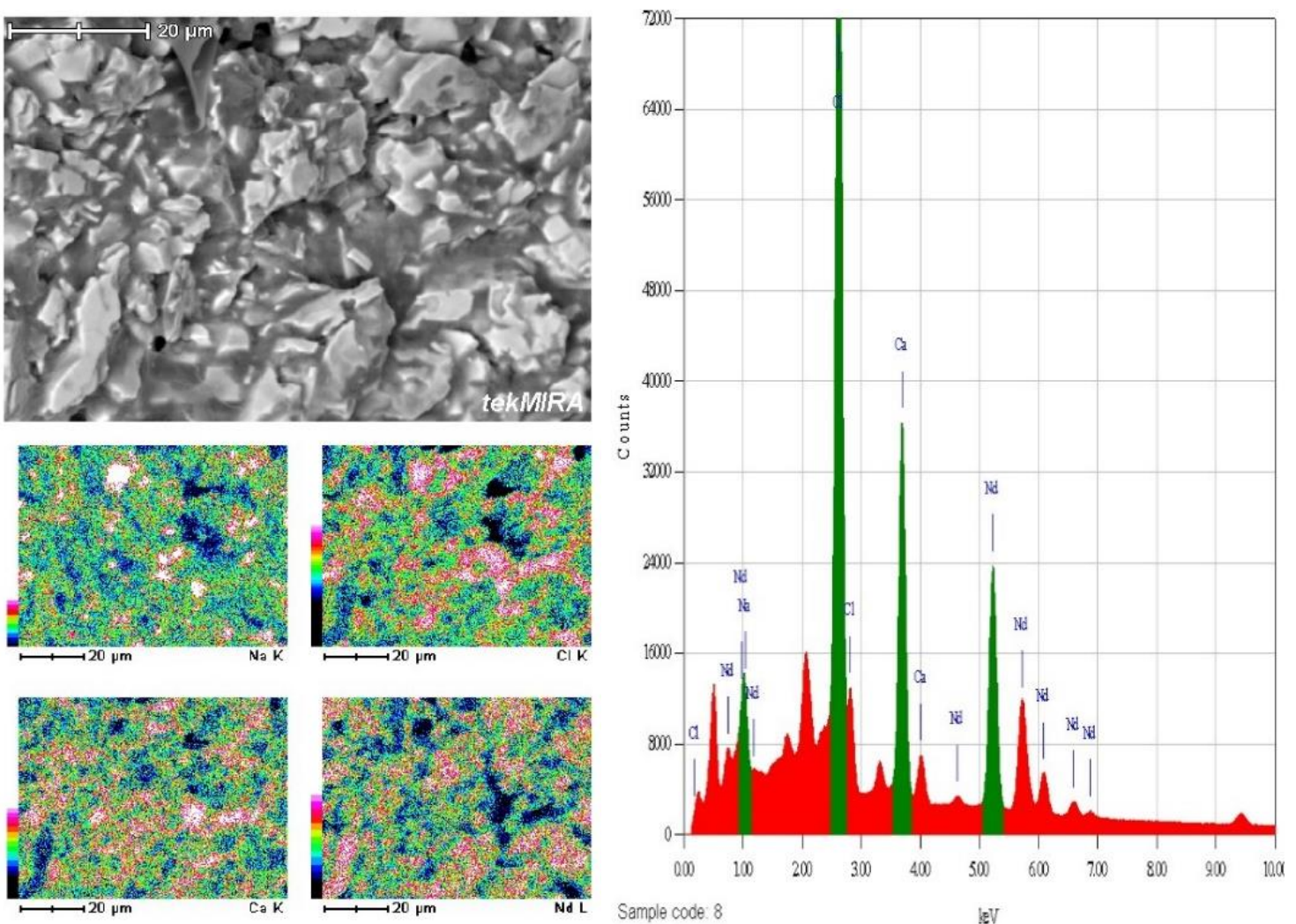

Sample code: 8

Figure 12. SEM-photomicrograph (left figure) and SEM-EDS (right figure) analysis results on sample 8. 
Thermodynamic Simulation of Neodymium Oxide Reduction into... Isyatun Rodliyah et al.
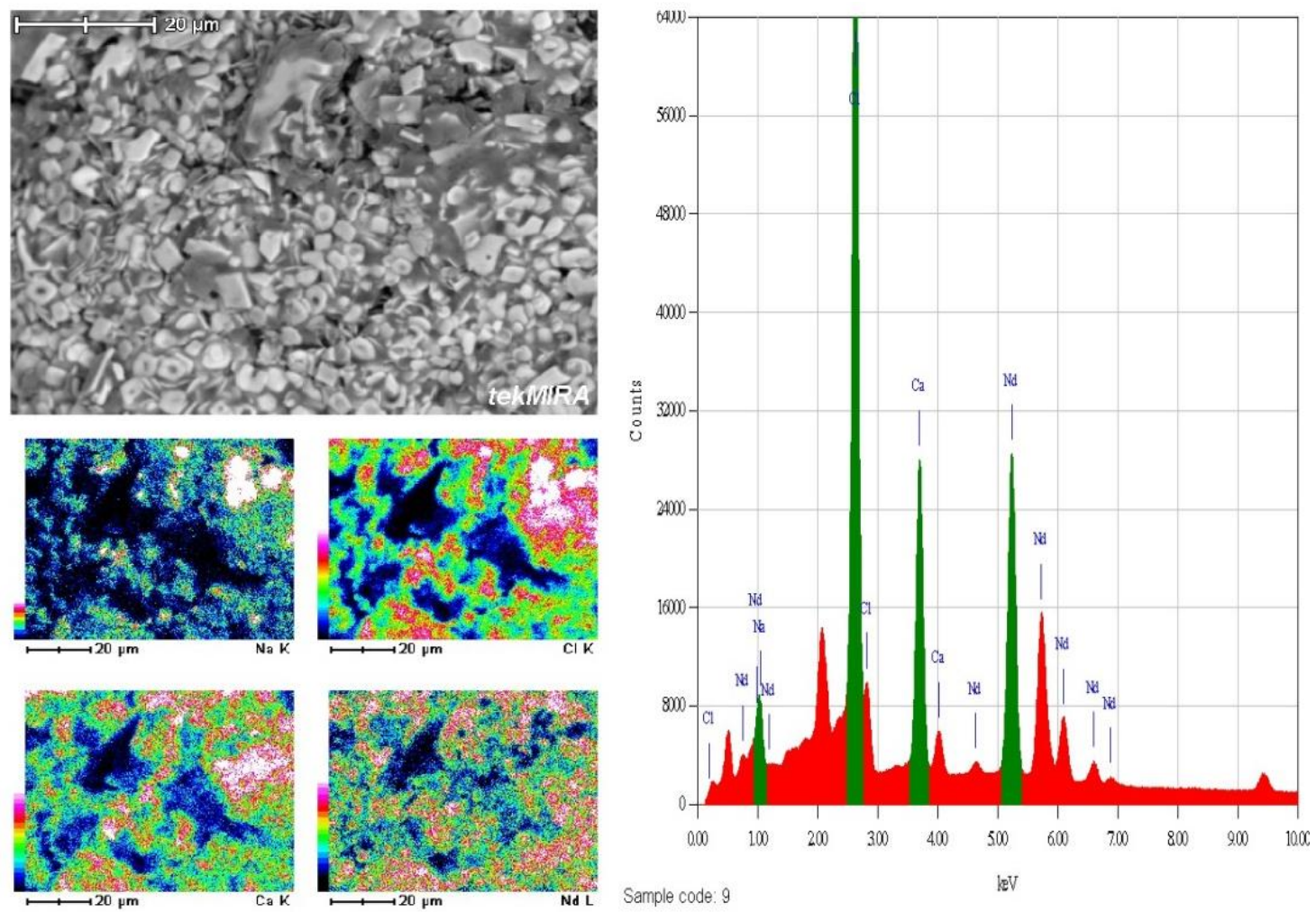

Sample code: 9

Figure 13. SEM-photomicrograph (left figure) and SEM-EDS (right figure) analysis results on sample 9.
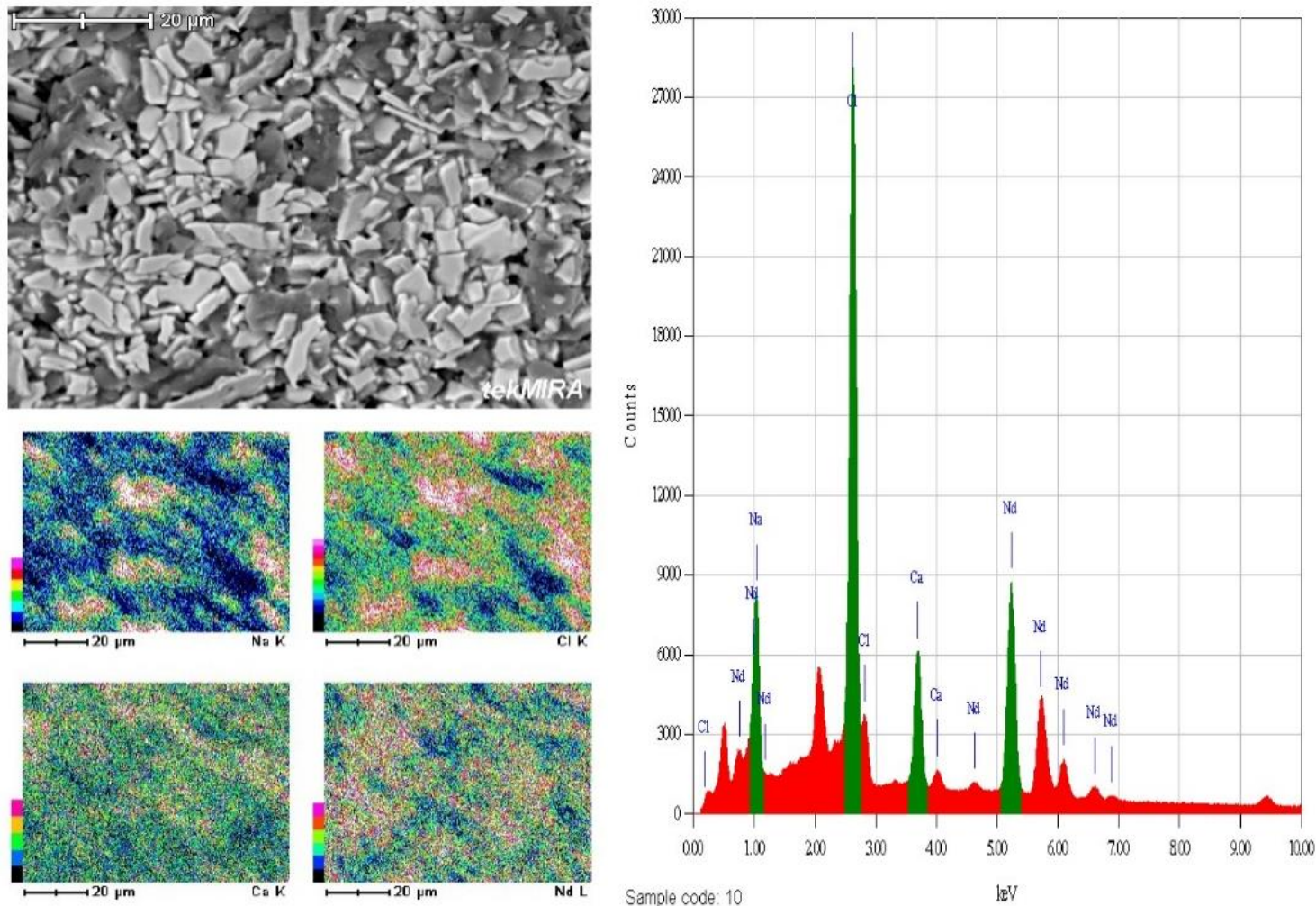

Figure 14. SEM-photomicrograph (left figure) and SEM-EDS (right figure) analysis results on sample 10. 
Based on the SEM-photomicrograph analysis results on Figures 8 to 14 , the $\mathrm{Nd}$ elements were shown with the brighter colours on the left side of the figures. While based on the SEM-EDS mapping on the right side of the figures, it can be concluded that the $\mathrm{Nd}$ element was well-scattered, shown by the red colour on each of the element's mapping results.

From the validation experiment, only samples 2 and 3 produced $\mathrm{Nd}$ metal. However, sample 6 with the same composition/parameter as sample 2 did not produce Nd metal. This might be caused by different treatment applied to the sample. Sample 2 was pelletized prior to the reduction process, while sample 6 was used directly in its existing form (powder).

Table 3 shows the result of the elemental composition analysis on sample 3 using $\mathrm{Nd}_{2} \mathrm{O}_{3}$ as the feed with the amount of $\mathrm{Ca}$ excessed twice of the stoichiometric calculation.

Based on Table 3, it can be concluded that $\mathrm{Nd}$ metal was formed through the reduction process with a grade of $49.25 \%$. However, $\mathrm{Na}, \mathrm{Ca}$, and $\mathrm{Cl}$ were still contained in the product (as the impurities of the Nd metal). $\mathrm{Nd}$ metal produced from the validation experiment for sample no. 3 shown in Figure 15.

Table 3. Result of the elemental composition analysis on sample 3 using $\mathrm{Nd}_{2} \mathrm{O}_{3}$ as the feed with the amount of $\mathrm{C}$ at twice excessed of the stoichiometric calculation

\begin{tabular}{lc}
\hline \multicolumn{1}{c}{ Elements } & Composition (\%) \\
\hline Neodymium $(\mathrm{Nd})$ & 49.25 \\
Chloride $(\mathrm{Cl})$ & 25.00 \\
Sodium $(\mathrm{Na})$ & 5.35 \\
\hline
\end{tabular}

Experimental results carried out to validate Factsage's thermodynamics simulations generally shows similar results. Factsage result showed that both samples no. 2 and 3 produced $\mathrm{Nd}$ metal. However, from the validation experiment, only sample no. 3 produced $\mathrm{Nd}$ metal. The difference in the results can be caused by the non-ideal condition in the validation experiments, on the contrary to the conditions in the Factsage's thermodynamics simulation. For example, the presence of oxygen in the reduction process; it was an 'easy' task to eliminate oxygen in the simulation but not in the real experiment. Thus, this may lead to the result's difference, including the formation of the metal.

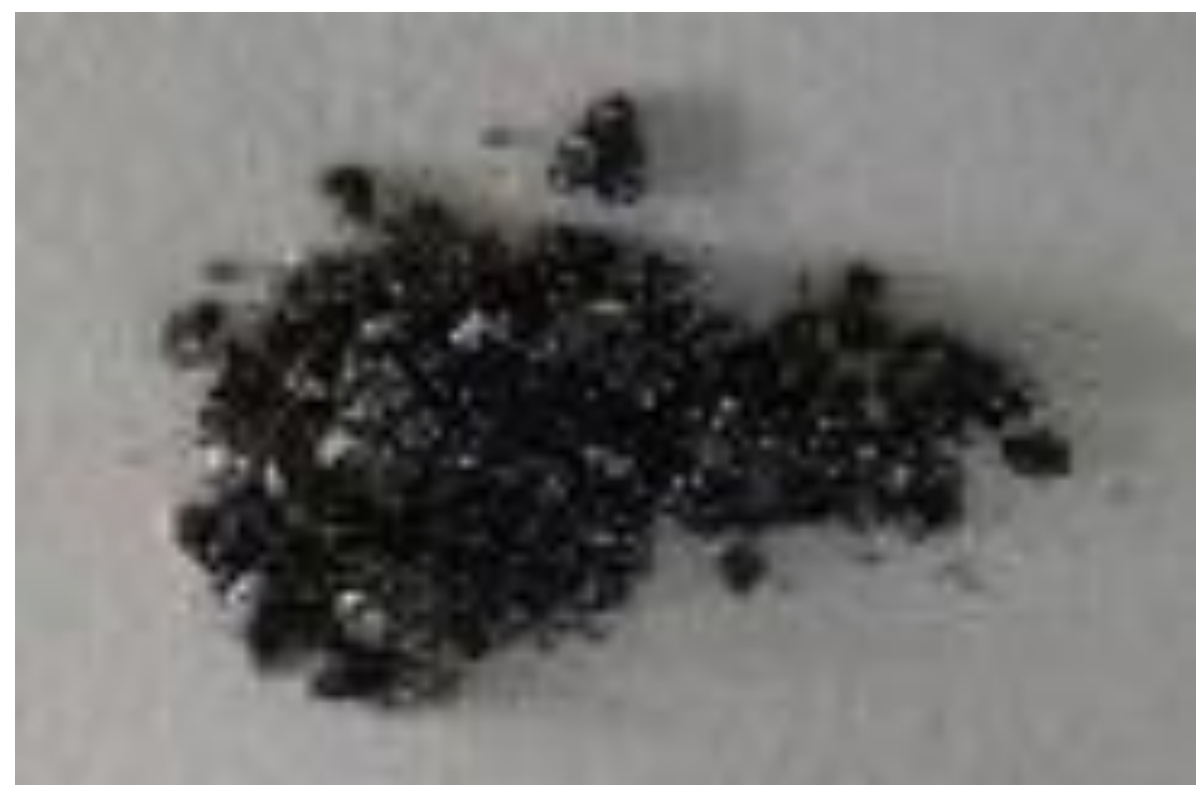

Figure 15. Nd metal produced using 1 Gram of $\mathrm{Nd}_{2} \mathrm{O}_{3}$. 


\section{CONCLUSION}

The validation experiment shows a similar result with the preceding thermodynamic simulation using Factsage software. However, some difference in the product resulted might be due to the different condition between the real experiment (nonideal) and thermodynamic simulation (ideal).

Reduction of rare earth metal oxides into their metals, particularly for $\mathrm{Nd}$, can be carried out through metallothermic methods and generate a product with more than $49 \%$ of metal.

\section{ACKNOWLEDGEMENTS}

The authors would like to express their gratitude to ESDM's R\&D and RISTEK DIKTI's projects for the funds given complete this research. The authors would also wish to thank to all colleagues for their help during this experimental works.

\section{REFERENCES}

Ames Laboratory (2017) The Ames process for rare earth metals, www.ameslab.gov. Available

at: https://www.ameslab.gov/mpc/the-amesprocess-rare-earth-metals.

Atmawinata, A. (2011) Pengembangan industri REE di Indonesia. Jakarta.

Benecki, W. T. (2008) "A producer's and buyer's perspective: The permanent magnet outlook," in Magnetic 2008 Conference. Denver, Colorado: MRAM, pp. 1-37.

Biswas, A., Sharma, I. G., Kale, G. B. and Bose, D. K. (1998) "Synthesis of neodymium aluminide by aluminothermic reduction of neodymium oxide," Metallurgical and Materials Transactions B, 29(2), pp. 309-315. doi: 10.1007/s11663-9980107-x.

De Campos, M. F., Rodrigues, D. and De Castro, J. A. (2014) "From neodymium oxide to NdFeB alloy: An overview on the reduction methods," in REPM 2014 23rd International Workshop on Rare Earth and Future Permanent Magnets and Their Applications. Annapolis, USA: Research Evaluation and Performance Measurement, pp. 358-360. doi: 10.13140/RG.2.1.3487.0807.
Claux, B., Serp, J. and Fouletier, J. (2011) "Electrochemical reduction of cerium oxide into metal," Electrochimica Acta, 56(7), pp. 2771-2780. doi: 10.1016/j.electacta.2010.12.040.

Ellingham, H. J. T. (1944) "Reducibility of oxides and sulphides in metallurgical processes," Journal of the Society of Chemical Industry, 63(5), pp. 125-133.

Gupta, C. K. and Krishnamurthy, N. (2005) Extractive Metallurgy of Rare Earth. CRC Press.

Koltun, P. and Tharumarajah, A. (2014) "Life cycle impact of rare earth elements," ISRN Metallurgy, 2014, pp. 1-10. doi: $10.1155 / 2014 / 907536$.

Krishnamurthy, N. and Gupta, C. K. (2015) Extractive metallurgy of rare earths. 2nd ed. CRC Press.

Lee, M. W., Jeong, S. M., Sohn, J. M. and Lee, S. H. (2016) "A study on electrochemical reduction of rare earth oxides in molten LiCl-Li2O salt," in Transactions of the Korean Nuclear Society Spring Meeting. Jeju, Korea: Korean Nuclear Society, pp. 1-2. Available at: https://www.kns.org/files/pre_paper/35/1 6S-199정상문.pdf.

Manaf, A. (2007) "Potensi bahan lokal dalam pengembangan material magnet untuk industri di Indonesia," Jurnal Sains Materi Indonesia, Ed. Khusus, pp. 1723. Available at: http://jusami.batan.go.id/terbitan-laludetail-materi.php?thn=2007\&id=47.

Riaño, S. and Binnemans, K. (2015) "Extraction and separation of neodymium and dysprosium from used NdFeB magnets: an application of ionic liquids in solvent extraction towards the recycling of magnets," Green Chemistry, 17(5), pp. 2931-2942. doi: 10.1039/C5GC00230C.

Richardson, F. D. and Jeffes, J. H. E. (1948) "The thermodynamic of substances of interest in iron and steelmaking from 0 to $2400^{\circ} \mathrm{C}$, I. Oxides," J. Iron Steel Inst., 160 , pp. 261-270.

Riedemann, T. (2011) High Purity Rare Earth Metals in Separation.

Saleh, N. (2015) "Preparation of metallic cerium by metallothermic reduction using cerium oxide as raw material," Indonesian Mining Journal, 18(2), pp. 
INDONESIAN MINING JOURNAL Vol. 21, No. 1, April $2018: 21$ - 34

82-91. Available at: http://jurnal.tekmira.esdm.go.id/index.ph p/imj/article/view/292.

Sharma, R. A. (1986) "Metallothermic reduction of rare earth oxides."

Weber, R. J. and Reisman, D. J. (2012) Rare earth elements: $A$ review of production, processing, recycling and associated environmental issues. Cincinnati, $\mathrm{OH}$ : EPA U.S. Environmental Protection Agency. Available at: https://nepis.epa.gov/Exe/ZyNET.exe/P1
00EUBC.txt?ZyActionD=ZyDocument\&Cli ent=EPA\&Index $=2011 \quad$ Thru 2015\%7C1995 Thru 1999\%7C1981 Thru 1985\%7C2006 Thru 2010\%7C1991 Thru 1994\%7C1976 Thru 1980\%7C2000 Thru $2005 \% 7 C 1986$ Thru 1990\%7CPrior to 1976\%7CHardcopy Publica.

Zhu, H. (2014) "Rare earth metal production by molten salt electrolysis," in Encyclopedia of Applied Electrochemistry. New York, NY: Springer New York, pp. 1765-1772. doi: 10.1007/978-1-4419-6996-5_455. 